\title{
The prospect of obtaining beneficial mineral and vitamin contents in cow's milk through feed
}

\author{
C. Swensson ${ }^{1,2}$ and H. Lindmark-Månsson ${ }^{1}$ \\ ${ }^{1}$ Swedish Dairy Association \\ Scheelevägen 18, SE-223 63 Lund, Sweden \\ ${ }^{2}$ Unit of Rural Buildings and Animal Husbandry, \\ Faculty of Landscape Planning, Horticulture and Agricultural Science, \\ Swedish University of Agricultural Sciences \\ P.O. Box 59, SE-230 53 Alnarp, Sweden
}

\begin{abstract}
The dairy industry is searching for add-values in milk that will promote the sale of milk. Several minerals and vitamins are important in this aspect. One easy way of improving milk quality is to change dairy cow diet. The concentration of selenium and iodine is greatly influenced by dairy cow diet. Both vitamin A and E concentrations in milk can be altered by dairy cow diet. Preferable diets are pasture and/or high-quality forage. Most important for rumen synthesis of vitamins of the Bcomplex are a well-functioning rumen, which means feed consisting of high quality forage.
\end{abstract}

KEY WORDS: dairy production, cow diet, milk quality, human health

\section{INTRODUCTION}

Milk is one of the essential foods representing an important part of the human diet. It is an excellent source of protein and calcium and also of many vitamins and trace elements, such as zinc, selenium and iodine. The composition of cow's milk is of great importance for the dairy industry. It is fundamental for the value of milk and affects its nutritional value as well as its processability. Factors influencing the composition of milk are internal factors, e.g., the breed of cow, and external factors, such as type of feed, seasonal changes, milking frequency and milking systems. New techniques in milk production and dairy plants, and also new dairy products, will place new demands on milk composition.

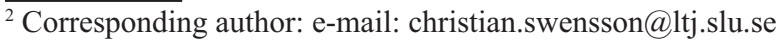


There is also a need to "redesign" milk, the main reason being that milk is expensive to produce, both in economic and energetic terms, compared with vegetable products (Boland et al., 2001).

The focus must be on the specific value of milk. One important aspect is its health value. Examples are milk as a source of calcium and several vitamins such as vitamins $\mathrm{A}$ and $\mathrm{E}$. The aim of this review is to elucidate the prospect of obtaining favourable mineral and vitamin contents in cow's milk through feeding. Selected minerals and vitamins have been studied due to their possibility to improve the nutritional value of milk.

\section{WHAT ARE FAVOURABLE MINERAL AND VITAMIN CONTENTS IN MILK?}

The nutritive value of milk has long been recognized. The nutritional role of milk as a component of the human diet has traditionally been evaluated based on its overall contribution of essential and non-essential nutrients to a high-quality diet to promote growth and development (Huth et al., 2006). It is becoming increasingly evident that foods naturally containing high levels of nutrients, such as milk and other dairy products, improve bone growth and can

Table 1. The contributions of nutrients from major animal groups, per capita per day, and expressed as a percentage of the total in the US food supply (modified from Beitz, 2005)

\begin{tabular}{|c|c|c|c|c|c|c|c|c|}
\hline \multirow{3}{*}{ Nutrient } & \multicolumn{6}{|c|}{ Animal food group } & \multirow{2}{*}{\multicolumn{2}{|c|}{$\begin{array}{l}\text { Total from } \\
\text { animal foods }\end{array}$}} \\
\hline & \multicolumn{2}{|c|}{$\begin{array}{l}\text { meat, poultry } \\
\text { and fish }\end{array}$} & \multicolumn{2}{|c|}{ dairy products } & \multicolumn{2}{|c|}{ eggs } & & \\
\hline & 1970 & 2000 & 1970 & 2000 & 1970 & 2000 & 1970 & 2000 \\
\hline Vitamin A & 36.0 & 27.0 & 21.8 & 22.1 & 6.7 & 5.3 & 64.5 & 54.4 \\
\hline Carotene & 0.0 & 0.0 & 3.3 & 2.1 & 0.0 & 0.0 & 3.3 & 2.1 \\
\hline Vitamin E & 5.4 & 4.0 & 3.9 & 2.4 & 3.4 & 1.9 & 12.7 & 8.3 \\
\hline Vitamin C & 2.4 & 2.0 & 4.2 & 2.5 & 0 & 0 & 6.6 & 4.5 \\
\hline Thiamin & 25.1 & 17.5 & 8.9 & 4.7 & 1.3 & 0.7 & 35.3 & 22.9 \\
\hline Riboflavin & 21.6 & 16.7 & 38.4 & 26.3 & 9.5 & 6.1 & 69.5 & 49.1 \\
\hline Niacin & 43.9 & 35.7 & 2.2 & 1.2 & 0.1 & 0.1 & 46.2 & 37.0 \\
\hline Vitamin $B_{6}$ & 38.2 & 34.7 & 12.1 & 8.7 & 2.9 & 1.9 & 53.2 & 45.3 \\
\hline Folate & 9.8 & 2.7 & 9.1 & 2.6 & 9.1 & 2.6 & 7.0 & 1.8 \\
\hline Vitamin $B_{12}$ & 73.3 & 75.2 & 20.3 & 20.3 & 4.5 & 4.3 & 98.1 & 99.8 \\
\hline Calcium & 2.8 & 3.2 & 75.6 & 72.2 & 2.3 & 1.8 & 80.7 & 77.2 \\
\hline Phosphorus & 25.6 & 24.8 & 36.7 & 32.7 & 5.3 & 3.8 & 67.4 & 61.3 \\
\hline Magnesium & 12.8 & 12.6 & 20.8 & 15.8 & 1.3 & 0.9 & 34.9 & 29.3 \\
\hline Iron & 22.7 & 15.6 & 2.4 & 1.9 & 4.0 & 2.2 & 29.1 & 19.7 \\
\hline Zinc & 46.9 & 37.8 & 19.4 & 16.8 & 3.9 & 2.6 & 10.2 & 57.2 \\
\hline Potassium & 16.6 & 16.8 & 23.7 & 18.1 & 1.5 & 1.1 & 41.8 & 36.0 \\
\hline Selenium & 18.4 & 28.1 & 16.2 & 10.9 & 10.5 & 6.1 & 45.1 & 45.1 \\
\hline Sodium & 24.7 & 19.3 & 25.9 & 32.8 & 4.0 & 3.3 & 54.6 & 55.4 \\
\hline
\end{tabular}


reduce the risk of other chronic diseases. In the United States the contribution from dairy products to the American diet regarding minerals and vitamins is of great importance (Table 1). In Sweden, the contribution from dairy products is of importance regarding vitamin $\mathrm{A}(11 \%$ of intake), vitamin $\mathrm{D}(15 \%)$, thiamine $(13 \%)$, vitamin $\mathrm{B}_{12}(16 \%)$ and vitamin $\mathrm{B}_{6}(8 \%)$ (Table 2$)$.

Table 2. The contributions of nutrients from dairy products, per capita per day, and as a percentage of the total in the Swedish food supply (modified from Riksmaten, 1997-1998)

\begin{tabular}{lcc}
\hline & Milk and yoghurt & Milk, yoghurt and cheese \\
\hline Vitamin A & 11 & 16 \\
Carotene & 1 & 3 \\
Vitamin E & 2 & 5 \\
Vitamin C & 0 & 0 \\
Thiamin & 13 & 14 \\
Riboflavin & 29 & 35 \\
Niacin & 9 & 14 \\
Vitamin B $_{6}$ & 8 & 9 \\
Folate & 13 & 15 \\
Vitamin B $_{12}$ & 16 & 22 \\
Calcium & 40 & 61 \\
Phosphorus & 23 & 34 \\
Magnesium & 13 & 16 \\
Iron & 1 & 2 \\
Zinc & 12 & 22 \\
Potassium & 15 & 16 \\
Selenium & 14 & 17 \\
& & \\
\hline
\end{tabular}

Beitz (2005) concluded that dairy products are one of the best sources of calcium, and that the content of iron and vitamin E should be increased in milk in order to contribute in a more complete way to human needs. Designer milk also offer the opportunity of new products (Boland et al., 2001). Hermansen et al. (2003) emphasized the importance of carotenes and tocopherols as antioxidants. These components contribute to the quality of milk fat. In the Nordic Nutrition Recommendations for 2004 (NNR, 2005) recommended daily intakes are given for 9 minerals and trace elements and 10 vitamins. Before changing the content of minerals and vitamins in milk the consequences on milk quality should be considered.

\section{FEEDING FOR A HIGH CONTENT OF MINERALS AND VITAMINS}

\section{Minerals and trace elements}

Values of the concentrations of minerals and trace elements reported in the literature show a wide variation (Renner et al., 1989). The reason for this is that 
levels are influenced by a variety of factors, including stage of lactation, season, nature of the soil, cattle, breed, feed and contaminants. Also, analytical errors have led to exceptionally high values of the concentrations of some trace elements, e.g., iodine, caused by the use of iodophores as udder disinfectants (Rasmussen et al., 1991). The chemical form of a nutrient is important because it may influence intestinal absorption and utilization and thus bioavailability. In Table 3 the absorption coefficients for dairy cows are summarized. Generally, nutrients that occur in a free form, such as soluble ions, are well absorbed, whereas those that are bound are often poorly absorbed.

\section{Macro-minerals}

Calcium. Over $90 \%$ of the $\mathrm{Ca}$ in the body is found in the teeth and bones where it is present as calcium phosphate (Flynn and Cashman, 1997). The content of $\mathrm{Ca}$ is approximately $1000 \mathrm{~g}$ in an average women and $1200 \mathrm{~g}$ in an average man (NNR, 2005). The remainder is present as an easily exchangeable pool in blood, extra-cellular fluid, and in the cells of the body. This free Ca plays a vital role in signal transduction, both within and between cells, in neuromuscular transmission, glandular secretion and in a large number of enzymatic reactions. Maintenance of a constant concentration is therefore of vital importance, and calcium homeostasis is probably the most highly regulated homeostatic mechanism. $\mathrm{Ca}$ is regarded as the most important mineral with respect to bone health. However, according to Cashman (2006), the exact relationship between $\mathrm{Ca}$ and bone health is not fully understood. In cow's milk $99 \%$ of the Ca is in the skim milk fraction (Flynn and Cashman, 1997). Two-thirds of the total $\mathrm{Ca}$ is found in the colloidal form associated with the casein micelles, either as calcium phosphate (about half of the total milk calcium) or as calcium ions bound to phosphoserine residues (about one-sixth of the total calcium). The remaining one-third is soluble. Ionized $\mathrm{Ca}$ in the soluble phase accounts for about $10 \%$ of the total $\mathrm{Ca}$. A small amount of calcium $(0.15 \%)$ is bound to $\alpha$-lactalbumin. The bioavailability of Ca in milk is high (Guéguen and Pointillart, 2000). The mean Ca absorption from cow's milk by healthy human adults has been reported to range from 21 to $45 \%$ (Table 3). Some components in milk such as lactose and phosphopeptide may enhance calcium absorption. The $\mathrm{Ca}$ in milk and other dairy products is absorbed much better than the $\mathrm{Ca}$ in spinach or watercress as these plants have high oxalate contents.

Dairy cow diet has relatively little effect on the concentration of $\mathrm{Ca}$ in milk because the skeleton of the cow acts as a reservoir of minerals. Plasma $\mathrm{Ca}$ is given high priority even with serious deficiencies (NRC, 2001). The homeostatic regulation of both $\mathrm{Ca}$ and $\mathrm{P}$ and the reservoirs of these minerals in the skeleton make it difficult to alter the concentrations of $\mathrm{Ca}$ and $\mathrm{P}$ in milk by altering dairy cow diet or by changing feeding strategy. Kamiya et al. (2005) compared a low- 
Table 3. Absorption coefficients for cows for macro- and trace minerals

\begin{tabular}{llc}
\hline Minerals & \multicolumn{1}{c}{ Absorption coefficients for cows } & 0.30 \\
\hline Calcium & Forage $^{1}$ & 0.60 \\
Phosphorus & Concentrates $^{1}$ & 0.64 \\
& USA; Forages $^{1}$ & 0.70 \\
& ${\text { USA; } \text { Concentrates }^{1}}$ & 0.55 \\
& Denmark $^{2}$ & 0.60 \\
& France $^{2}$ & 0.60 \\
Magnesium & The Netherlands $^{2}$ & 0.16 \\
Iron & Natural feedstuffs $^{1}$ & 0.10 \\
Zinc & All feed $^{1}$ & 0.10 \\
Potassium & All feed $^{1}$ & 0.90 \\
Selenium & All feed $^{1}$ & $0.40-0.65$ \\
& All feed $^{1}$ & $0.30-0.65$ \\
Sodium & All feed $^{2}$ & 0.90 \\
Chloride & All feed $^{1}$ & 0.90 \\
\hline
\end{tabular}

${ }^{1}$ NRC (2001), ${ }^{2}$ Aaes et al. (2003)

calcium diet $(0.43 \% \mathrm{Ca})$ with a high-calcium diet $(0.86 \% \mathrm{Ca})$ three weeks before parturition and found no difference in Ca content in the colostrum or milk. Breed is probably more important than the cow's diet: Jersey cows have a higher $\mathrm{Ca}$ concentration in milk than Holstein-Friesian cows (Knowles et al., 2006).

Phosphorus. $\mathrm{P}$ is abundant in the body, the largest amounts being found as hydroxyapatite in bones (NNR, 2005). It occurs as organic and inorganic phosphates in all body tissues and fluids, is an essential component of many biological molecules, including lipids, proteins, carbohydrates and nucleic acids, and plays a central role in the metabolism (Flynn and Cashman, 1997). Of the $\mathrm{P}$ in milk, $20 \%$ is found in ester linkages with the hydroxyl groups of serine and threonine residues of the caseins, $40 \%$ in inorganic phosphate in casein micelles and the remainder in lipids and water-soluble esters (Renner et al., 1989). Feed has relatively little effect on the concentration of $\mathrm{P}$ in milk for the same reason as $\mathrm{Ca}$ : the skeleton acts as a reservoir of minerals. The feeding of $\mathrm{P}$ to dairy cows has been questioned, due to concerns regarding eutrophication of the environment. The $\mathrm{P}$ feeding norm has been decreased in the USA, the Netherlands, Germany, Denmark and Sweden during the past decade (Aaes et al., 2003; Spörndly, 2003; Pfeffer et al., 2005). High-yielding cows often have problems associated with overfeeding of P (Aaes et al., 2003; Pfeffer et al., 2005). However, the concentrations of P in milk from 1970 compared to $\mathrm{P}$ in milk from 1996 did not increase during this period (Lindmark-Månsson et al., 2003).

Magnesium. According to Cashman (2003) there is little evidence of dietary deficiency of magnesium in human beings, except in serious diseases. In dairy 
cows, $\mathrm{Mg}$ is important for several functions such as muscle function, nerve conduction and, together with $\mathrm{P}$ and $\mathrm{Ca}$, bone mineral formation. $\mathrm{Mg}$ is also a cofactor in several metabolic pathways (NRC, 2001). In contrast to $\mathrm{Ca}$ and $\mathrm{P}$, maintaining normal values of $\mathrm{Mg}$ in the blood plasma of dairy cows is almost totally dependent on the absorption of dietary $\mathrm{Mg}$ (NRC, 2001). However, it is difficult to alter the concentration in bovine milk by altering dairy cow diet. In cow's milk $98-100 \%$ of the magnesium is in the skim milk phase, where $65 \%$ of the magnesium is in a soluble form ( $40 \%$ as magnesium citrate, $7 \%$ as magnesium phosphate and $16 \%$ as free magnesium ion), while the remainder is colloidal and is associated with the casein micelle.

Potassium. The major proportion of potassium in the body (90\%) is found in the cells, and $\mathrm{K}$ is quantitatively the most important intracellular cation (NNR, 2005). Extra-cellular potassium, which constitutes the remaining $2 \%$, is important for the regulation of the membrane potential of the cells, and thus nerve and muscle function. The important role of $\mathrm{K}$ in regulating blood pressure, in both the general population and in people with high blood pressure, has been demonstrated repeatedly in epidemiological as well as clinical studies, and is today well established (Vaskonen, 2003). K in milk is entirely soluble, completely ionic and fully available for absorption (Renner et al., 1989). Together with sodium and chloride, this monovalent ion is among the most prevalent minerals in milk (Atkinson, 1995). Major changes in the concentration of the major monovalent cations in milk, such as $\mathrm{K}$, are associated with conditions that promote opening of the membranes between epithelial cells (Atkinson, 1995). As for Mg, the dairy cow is dependent on daily intake of $\mathrm{K}$. However, the concentration in milk is rather constant, even if the daily intake of K fluctuates (NRC, 2001). Overfeeding dairy cows with K has a detrimental effect on the absorption of $\mathrm{Ca}$ and $\mathrm{Mg}$.

Sodium and chloride. Na is the most important cation in extracellular fluids and regulates the osmolarity, acid-base balance and the membrane potential of cells. Chloride is the most important anion in extracellular fluid and is very important in the maintenance of fluid and electrolyte balance (Cashman, 2003). There is normally no dietary deficiency of $\mathrm{Na}$ or $\mathrm{Cl}$ in humans. On the contrary, there is probably a need in the Western world to decrease the intake of salt $(\mathrm{NaCl})$ because of its influence on hypertension (von Wowern, 2006).

In summary; it would be beneficial for human nutrition to increase the concentration of $\mathrm{Ca}$ and $\mathrm{K}$ in bovine milk, but it seems to be difficult or impossible due to physiological reasons. Regarding $\mathrm{P}$, there is no great advantage in increasing the concentration in milk and it is difficult to influence the concentration in dairy cow milk by altering the dairy cow diet. Due to environmental reasons it is more important to decrease the concentration of $\mathrm{P}$ in dairy cow diet as much as possible. Overfeeding dairy cows with $\mathrm{P}$ means more $\mathrm{P}$ in manure and environmental 
problems. Increasing $\mathrm{Mg}$ in milk probably has no positive effect on humans and it is also difficult to influence the content in milk by changing dairy cow diet. Finally, there is a great deal of evidence that the overall dietary intake of salt should be decreased, hence, there is no need to increase the concentration of sodium or chloride in milk.

\section{Trace elements}

Fourteen trace elements are considered essential to humans, three of which are of special interest, namely selenium, iodine and iron, due to their positive effects on human health and the possibility of influencing the content in milk by changing dairy cow diet.

Selenium. Most of the Se in both human and bovine milk is protein bound (Debski et al., 1987). In bovine milk 60-80\% of the Se is associated with the caseins, $20-40 \%$ with the whey proteins and $10-25 \%$ with the low-molecular fraction. Se occurs mainly as the amino acids selenocysteine and selenomethionine, which differ from cysteine and methionine in having a Se atom in place of the sulphur atom.

Selenium amino acids are principal dietary forms of the element available to free-living animals, but Se is often supplied in inorganic form in experimental diets and in supplements (Levander and Burk, 1996). Its chemical form in foods, the presence of other food constituents and the physiological status of the individual influence the bioavailability of Se. This has been studied mainly in animals, and only a few studies have been performed on man (Mutanen et al., 1986; Fairweather-Tait, 1997).

The dietary level of antioxidants, e.g., vitamins $\mathrm{C}$ and $\mathrm{E}$, methionine and total protein may enhance Se bioavailability (Levander, 1991). Se is very well absorbed from milk, as demonstrated in subjects having undergone ileostomy (Chen et al., 2004). The amount of Se in milk is, however, influenced by other factors, such as the form and bioavailability of Se in the diet, as well as interactions with other nutrients. A value of $18 \mu \mathrm{g} \mathrm{kg}^{-1}$ in Swedish bulk milk was reported in 1996 (Table 4). The Se content in Swedish milk increased by approximately $80 \%$ from the early 1970s up to 1996, probably due to the increased addition of Se in dairy cow feed. It is possible to change the content of Se in cow's milk by feeding. However, the uptake of Se by dairy cows differs depending on the source. Feeding with inorganic Se is not as efficient as feeding with organic selenium. With respect to the use of different forms of Se in food, yeast was found to be more effective than selenite in increasing the Se content in maternal serum and milk (Kumpulainen et al., 1985). Similarly, the transfer of dietary Se into bovine milk was found to be markedly more efficient with selenized yeast than when using sodium selenite as 
a feed supplement (Knowles et al., 1999; Ortman and Pehrson, 1999). According to Givens (2004) the uptake of selenized yeast was 3-5 times higher than inorganic selenium. In another experiment $10-18 \%$ of the selenium given in dairy cow diet was found in the milk (Juniper et al., 2006). The same study also indicated that high levels of Se in the cows' milk had no negative effects on other important components of milk. Se has also been administered to cows to minimize the oxidation of milk fat (Nicholson et al., 1991). Especially with vitamin $\mathrm{E}$ there is an interaction with Se as antioxidants (Christensen et al., 2006). This interaction is rather complicated and can be synergetic or antagonistic. Se is potentially the most poisonous essential trace mineral to animals. The US Food and Drug Administration have set an upper limit on Se in milk, $14 \mu \mathrm{g} / \mathrm{L}$ (Weiss, 2005; Christensen et al., 2006). Within EU, there is no upper limit in milk, although 20 $\mu \mathrm{g} / \mathrm{L}$ has been suggested in Finland (Givens et al., 2004). Another problem with EU legislation, only inorganic feed additives (sodium selenite and sodium selenate) are allowed and, hence, not selenized yeast is allowed (Givens et al., 2004). The content of Se in milk is influenced by regional differences, i.e. the Se status of the soil. Interesting findings have been made in Finland, where the Se content of milk was doubled in a short time, by increasing the level of Se in mineral fertilizer (Ekholm et al., 1993; Syrjäla-Qvist and Aspila, 1993). In a Swedish comparison between organic and conventional milk a lower level of Se was found in organic milk (Toledo et al., 2002). In a similar Danish investigation no difference was found in Se concentration with different production systems (Hermansen et al., 2005). In Table 4 values of Se content in feed and milk and recommendations for daily intake for dairy cows are presented. To our knowledge, there is no obvious reason for the difference in Se norms between different countries.

Table 4. Concentrations of selenium and iodine in selected feed and milk and recommended daily intake for dairy cows

\begin{tabular}{llcllll}
\hline Item & \multicolumn{2}{c}{$\begin{array}{c}\text { In feed Sweden } \\
\mathrm{mg} / \mathrm{kg}\end{array}$} & \multicolumn{2}{c}{$\begin{array}{c}\text { Recommended daily intake } \\
\text { for dairy cows } \\
\mathrm{mg} / \mathrm{kg} \text { DM }\end{array}$} & \multicolumn{2}{c}{$\begin{array}{c}\text { In milk } \\
\mu \mathrm{g} / 100 \mathrm{~g}\end{array}$} \\
\hline Selenium & Roughage & 0.02 & Sweden & 0.20 & Sweden & $1.8^{1}$ \\
& Barley & 0.01 & Denmark & 0.10 & Denmark & $3.0^{2}$ \\
& Oatley & 0.01 & USA & 0.30 & & \\
& Soya meal & 0.19 & & & & \\
& Rapeseed meal & 0.09 & & & & \\
Iodine & & & & & & \\
& Roughage & - & Sweden (Milking cows) & 0.60 & Sweden & $14.0^{1}$ \\
& Barley & 0.3 & Denmark & 0.10 & USA & $23.0^{2}$ \\
& Oatley & 0.1 & USA & 0.30 & & \\
& Rapeseed meal & 0.7 & & & & \\
\hline
\end{tabular}

${ }^{1}$ Lindmark-Månsson et al. (2003); ${ }^{2}$ Larsson and Sehestad ( 2003); ${ }^{3}$ Pennington (1990) 
Iodine. Iodine has long been recognized as an essential micronutrient for humans and animals (Saikat et al., 2004). The importance of I arises from the fact that it is a constituent of the thyroid hormones. These hormones are essential for normal growth and physical and mental development in animals and humans (Hetzel, 1998). I deficiency is the world's most prevalent cause of brain damage. I is present in foods mainly as iodide and, to a lesser extent, covalently bound to amino acids (Brody, 1994). Iodide is rapidly absorbed by the gut and assimilated by the thyroid gland for use in producing thyroid hormones. The I present as part of amino acids, that is, as part of tyrosine, is somewhat less well absorbed (Hetzel, 1998). Once the need for thyroidal I has been met, the kidneys excrete excess I, so the urinary I output reflects the I intake. I absorption and utilization may also be affected by goitrogens, mainly sulphur-containing glucosides (NNR, 2005). These are dietary constituents occurring, for example, in cabbage, turnips and rapeseed, which may act as competitors for I, e.g., thiocyanates. Most of the I in milk (80$90 \%$ ) is in the inorganic form, mainly as iodide in the water-soluble fraction, while $5-13 \%$ is bound to proteins through either covalent bonds or loose physical associations, with less than $0.1 \%$ bound to fat (Cashman, 2003).

Iodine enters the cow's diet from grass, concentrated feeds or from iodized salts (Table 4). The topsoil of the pastures on which the cows graze has been shown to make an important contribution to the I content in milk. There is a good relation between the content of I in dairy cow diet and the concentration of I in milk (Swanson et al., 1990).

Another possible source of I in milk is that which arises from the use of iodophores as disinfectants in dairy plants and as teat dips. I is the only trace element for which there have been suggestions of excessive amounts in cow's milk (Cashman, 2003). Data from various countries on the I concentration in cow's milk indicate mean values of $100-770 \mu \mathrm{g} \mathrm{L}^{-1}$ with a wide range of values from 20 to $>4000 \mu \mathrm{g} \mathrm{L}^{-1}$ (Flynn and Cashman, 1997). In earlier studies, prior to 1970, I in milk rarely exceeded $100 \mu \mathrm{g} \mathrm{L}^{-1}$. In Sweden, the I content in milk was found to be $140 \mu \mathrm{g} \mathrm{L}^{-1}$ in 1996 (Lindmark Månsson et al., 2003).

The contents of I in Swedish dairy milk have increased by $75 \%$ compared with the investigation in 1973 (Swedish Dairy Association, 1973). A similar increase in I content has been observed in milk from the UK, from $15 \mu \mathrm{g} 100 \mathrm{~g}^{-1}$ in $1991 / 1992$ to $30.3 \mu \mathrm{g} 100 \mathrm{~g}^{-1}$ in 1995, and in a follow-up investigation in 1998/1999 the content was found to be $31.1 \mu \mathrm{g} 100 \mathrm{~g} \mathrm{~g}^{-1}$ (UK Ministry of Agriculture, 2000). The I level in Irish milk is close to that found in milk in the UK (O'Brien et al., 1999). As for Se, there is a difference in I norms between different countries (Table 4).

Iron. Fe has several functions in the body; it is a component of heme found in myoglobin and haemoglobin, and it acts as cofactors of several enzymes such as catalase, cytochrome oxidase and ferredoxin (NRC, 2001). Fe is an important 
trace element in humans, especially for women. During pregnancy clinical iron deficiency occur among as many as $20 \%$ of all women (MacRae et al., 2005; Knowles et al., 2006). Only a minor part of Fe in the human diet, $5-15 \%$, is absorbed (Péréz et al., 2002). In dairy the industry, the Fe-binding glycoprotein in milk, lactoferrin, has been recognized due to various positive health effects (Wakabayashi et al., 2006).

On the other hand, Fe deficiency in adult cattle is unusual (NRC, 2001). According to Knowles et al. (2006) there are indications that it is possible to increase the concentration of $\mathrm{Fe}$ in milk by changing dairy cow diet. However, several obstacles must be overcome, such as the bioavailability of $\mathrm{Fe}$ and interactions with other chemical compounds (Knowles et al., 2006).

Zinc. Zinc has several important functions in humans. It is involved in the immune system and is essential for growth and development. Many hormones contain Zn, such as insulin and reproduction hormones (Cashman, 2003). According to Cashman (2003) there is a considerable difference in human absorption of $\mathrm{Zn}$ depending on the milk source. $\mathrm{Zn}$ from human milk is more easily absorbed than that in bovine milk. In Western countries milk and dairy products contribute 19$31 \%$ of the total $\mathrm{Zn}$ intake. Zinc also has a positive effect on the immune system of cows (Lindmark-Månsson et al., 2000). Zn deficiency among dairy cows is probably not a serious issue in the Scandinavian countries (Aaes et al., 2003). However, a high uptake of copper or cadmium is antagonistic to $\mathrm{Zn}$ uptake. It is difficult to change the concentration of $\mathrm{Zn}$ in milk by altering the dairy cow diet. Lindmark-Månsson et al. (2000) reported that supplementing dairy cow diet with Zn prolonged the growth of starter cultures. Gustafson et al. (2007) report that the equipment in the cow shed is probably one source of $\mathrm{Zn}$.

In summary; the concentrations of Se and I in milk are rather easy to alter by changing dairy cow diet. It would be desirable to increase the concentration of $\mathrm{Fe}$ in milk, but unfortunately this appears to be difficult at the moment. An increased content of Fe may also increase the oxidation in milk.

\section{Vitamins}

All known vitamins are found in milk (Renner et al., 1989). The relative contributions from cow's milk to the human dietary requirements vary, but for some vitamins, particularly riboflavin $\left(\mathrm{B}_{2}\right)$ and vitamin $\mathrm{B}_{12}$, milk is a particularly rich source. The fat-soluble vitamins A, D, E and K, are, as their names imply, associated with the fat fraction of the milk, whereas the water-soluble vitamins of the B complex and vitamin $\mathrm{C}$ are associated with the non-fat, aqueous fraction, or whey. 
Fat-soluble vitamins. The concentrations of the fat-soluble vitamins A and $\mathrm{E}$ are dependent on the dietary intake of the cow and on the concentration of fat in the milk (Renner et al., 1989). Large seasonal variations are often seen in their concentration in milk. The vitamin D content is mainly influenced by the exposure of the animal's body to ultraviolet light (Renner et al., 1989). Because of the large amount of vitamin $\mathrm{K}$ synthesized by ruminal and intestinal bacteria, it is also unlikely, that dietary vitamin $\mathrm{K}$ has much, if any effect, on the level in milk (NRC, 2001). The breed of cow also has a significant effect on the concentration of fatsoluble vitamins in milk: high-fat milk (from Jersey and Guernsey cows) has a higher content of vitamin $\mathrm{E}$ and $\beta$-carotene, but a lower content of vitamin A due to a lower dioxygenase activity at the intestinal mucosa than milk from Friesian or Holstein cows. The yellow-orange colour of high-fat dairy products depends on the concentration of carotenoids, and hence on the diet of the animal. Carotenoids are not transported to the milk of goats and sheep, which is why their milk fat appear white compared to that of cows.

Vitamin A-carotenes. Vitamin A constitutes a group of chemically closely related compounds possessing the biological activity of retinol (Öste et al., 1997). Carotenes are precursors of retinol, i.e. vitamin A (Nozière et al., 2006b). Carotenes are a subgroup of the carotenoid family, which contains of more than 600 molecules and they are involved in the photosynthetic process. According to Nozière et al. (2006b), there are approximately 10 carotenoids in ruminant feeds, and the most important are $\beta$-carotene and lutein.

Vitamin A is essential to all vertebrates and has numerous important functions, for example, in vision, the maintenance of epithelial surfaces, immunodefence, growth, development and reproduction (NNR, 2005). Acute and chronic effects of vitamin A excess are well documented in the literature (Penniston and Tanumihardjo, 2006). Osteoporosis and hip fractures are associated with vitamin A intakes that are only twice the current recommended daily intake. The transfer of $\beta$-carotene from blood to milk seems to occur by passive diffusion (Jensen, 1995). The transfer of vitamin A from blood to milk is not determined by the vitamin A content of blood, presumably due to the strong regulation in the liver. Vitamin A is efficiently absorbed and utilized by humans at absorption rates of $70-90 \%$. Carotenoids are absorbed much less efficiently, at rates of $20-50 \%$, depending the individual's vitamin A status and other non-dietary factors.

The vitamin A activity in milk does not depend solely on the vitamin as such, but also on carotenoids, of which $\beta$-carotene is by far the most important (Renner et al., 1989). Carotenoids are abundant in plant material and appear in milk as the result of their ingestion by the cow. $\beta$-carotene is found in vegetative material, hence forage is a good source of $\beta$-carotene, while grain and grain by-products contain very little or no $\beta$-carotene. $\beta$-carotene is easily oxidized and concentrations decrease quickly during storage (NRC, 2001). Investigations of the concentration 
of vitamin A in roughage and concentrate show a considerable variation, thus indicating that vitamin values in feed tables are not reliable (Kristensen, 2003; Nadeau and Johansson, 2003). According to Nadeau and Johansson (2003) it is possible to retain the concentrations of $\beta$-carotene in silage if the silage is of high quality, the level of hygiene is good and the weather during harvest is sunny and dry. However, an investigation by Nozière et al. (2006a) shows a large difference in the concentration of $\beta$-carotene between silage and hay, the latter having a lower value. $\beta$-carotene is converted, to varying degrees, into vitamin $A$ in the body.

Depending on the breed of cow and the carotenoid intake, the conversion of $\beta$-carotene into vitamin $A$, which occurs mainly in the intestinal mucosa, involves enzymatic conversion to retinal, which is then reduced to retinol. Thus retinol and hydrolysed retinyl esters from the feed are absorbed and re-esterified. Vitamin A is present in cow's milk as retinol, retinol esters and carotene (Öste et al., 1997). In bulk milk the variation in retinol and carotenoid concentrations is reduced compared to the variation between and within the milk of individual cows. However, there are often seasonal and regional variations of retinol and carotenoid concentrations, which reflect the nature of the forage used (Nozière et al., 2006b). In Swedish dairy milk the retinol content was found to increase by over $30 \%$ from the winter months to the summer, from $30.7 \mu \mathrm{g} / 100 \mathrm{~g}$ in March to $40.7 \mu \mathrm{g} / 100 \mathrm{~g}$ in September (Lindmark Månsson, 2003).

Thus, to achieve a high concentration of $\beta$-carotene in milk, the importance of a cow diet with high-quality roughage, especially silage or pasture, cannot be underestimated. If the cow diet is supplemented with vitamin A, it is important to be aware that the destruction of vitamin A in the rumen can be high (NRC, 2001). In Sweden, low-fat milk is supplemented with both vitamin A and D. The goal is to achieve a concentrationof $25 \mu \mathrm{g}$ vitamin $\mathrm{A} / 100 \mathrm{~g}$ milk (www.mjolkframjandet.se, access 2006-11-19).

Vitamin E-tocopherols. Vitamin E has traditionally been used as a common term for two groups of components with biological vitamin $\mathrm{E}$ activity in mammals, tocopherols and tocotrienols, which are synthesized in plants (NNR, 2005). Vitamin E is essential for neurological function and acts as a lipid-soluble antioxidant. The vitamin $\mathrm{E}$ activity in plants is influenced by species, variety and stage of maturation, as well as by harvesting, processing and storage conditions (Morrissey and Kiely, 2003). The concentration of vitamin E in animal products is usually low, but such products may provide significant sources of this vitamin to humans because of their high consumption. In humans, vitamin $\mathrm{E}$ is taken up in the proximal part of the intestine, and uptake depends on the amount of food lipids, bile and pancreatic esterases that are present. It is emulsified together with fat-soluble components of the food. Lipolysis and emulsification of the lipid droplets formed then lead to the spontaneous formation of mixed micelles, which 
are absorbed at the brush border membrane of the mucosa by passive diffusion. It is generally believed that the absorption of tocopherols is incomplete and that tocopherol esters need to be hydrolysed prior to absorption (Öste et al., 1997). The principal form of vitamin $\mathrm{E}$ in milk is $\alpha$-tocopherol.

The vitamin E content of cow's milk is rather low and it depends to some extent on the feed. Summer milk generally has higher concentrations than winter milk, as illustrated by findings in Swedish dairy milk where the lowest content of $\alpha$ tocopherol, $92 \mu \mathrm{g} 100^{-1} \mathrm{~g}$, was found in February and the highest content, $110 \mu \mathrm{g}$ $100 \mathrm{~g}^{-1}$, in July (Lindmark-Månsson, 2003). According to NRC (2001), the most biologically active form of vitamin $\mathrm{E}$ is $\alpha$-tocopherol. There are eight different stereoisomers of vitamin E, RRR- $\alpha$-tocopherol has the highest biological activity (NRC, 2001; Krogh-Jensen, 2005). This naturally occurring isomer also has the highest biological function compared to synthetic stereoisomers (Meglia et al., 2006). In a study by Bourne et al. (2007) comparing the effects of parental and oral administration of vitamin $\mathrm{E}$ to dairy cows on plasma and milk concentrations, they were actually comparing the administration of two different isomers. The positive effects in dairy cows are several. Vitamin E improves reproduction efficiency by decreasing the retention time of the foetal membranes and there is also evidence of a reduction in the incidence of mastitis (Baldi, 2005). The recommended intake for dairy cows has been increased over the past 10-15 years; NRC recommended $15 \mathrm{IU}$ per $\mathrm{kg} \mathrm{DM}$ in 1989 and today the recommendation is $80 \mathrm{IU} / \mathrm{kg} \mathrm{DM}$ in the dry period and $20 \mathrm{IU} / \mathrm{kg} \mathrm{DM}$ during lactation (Baldi, 2005). According to McDowell et al. (1996) there is a significant amount of vitamin $\mathrm{E}$ in whole cereal grains, especially in the germ and in by-products containing the germ. The main feed source of vitamin $\mathrm{E}$ is forage, especially fresh forage. Important factors affecting the concentration of vitamin $\mathrm{E}$ in forage are the stage of maturity and storage conditions. Silage is better than hay as storage losses from hay can be substantial (McDowell et al., 1996; NRC, 2001).

\section{Water-soluble vitamins}

The water-soluble vitamins of the vitamin B complex are synthesized by rumen bacteria and this is the main source of these vitamins in milk (Renner et al., 1989). Vitamin $C$ is synthesized in the liver and possibly in the intestinal and kidney tissues.

$B$ vitamins. The general belief, according to Schwab et al. (2006) is that "dietary supply and ruminal synthesis are sufficient to meet dairy cow requirements of B vitamins". However, diets supplemented with biotin, thiamine, folic acid and vitamin $\mathrm{B}_{12}$ has been shown to have positive effects on lactation (Schwab et al., 2006). The importance of microbial synthesis was demonstrated in an American 
study where the apparent digestibility with different B-vitamins was investigated. The conclusion was that ruminal synthesis of B-vitamines was influenced by dietary forage and the non-fermentable carbohydrate (NFC) content of dairy cow diet. The highest amount of microbial synthesis was observed for niacin, riboflavin, $\mathrm{B}_{12}$, thiamin, $\mathrm{B}_{6}$, and folic acid. No biotin was found, either because none was synthesized or because more biotin was destroyed by ruminal microbes than synthesized (Schwab et al., 2006). It was also concluded that high forage content decreased ruminal apparent synthesis of folic acid and $\mathrm{B}_{12}$, and increasing NFCs in dairy cow diet increased the ruminal apparent synthesis of niacin and $\mathrm{B}_{12}$. Several investigations have presented results indicating higher milk yield and/or increased concentration of different milk components when dairy cow diets are supplemented with different types of B vitamins. Supplementing dairy cow diet with biotin increases milk yield, according to Majee et al. (2003). In an investigation carried out by Jaster and Ward (1990) a cow diet supplemented with nicotinamide led to greater milk production and a higher percentage fat. On the other hand, Nielsen and Ingvartsen (2000) concluded in a review of several investigations regarding niacin administration to dairy cows that supplementary niacin had no effect on milk production. However, there is little or no information on the influence of the concentration of B vitamins in milk, apart from folates and vitamin $\mathrm{B}_{12}$.

In an investigation of Swedish dairy milk, the content of all water-soluble vitamins, except biotin, showed a seasonal variation (Lindmark-Månsson et al., 2003). A possible explanation of this could be that the seasonal variation in the feed influences the synthesis of the ruminal microorganisms.

Folates. Folate is a generic term for a group of compounds that includes folic acid and derivatives having nutritional properties similar to folic acid (NNR, 2005). Folate is essential for one-carbon transfer reactions required in many metabolic pathways, including purine and pyrimidine biosynthesis (Öste et al., 1997). Folates serve as coenzymes and are required for normal cell division (NNR, 2005). One central folate-dependent reaction in amino acid metabolism is the remethylation of homocystein to methionine. The reaction requires vitamin $\mathrm{B}_{12}$. Homocystein is also removed by a reaction that requires vitamin $\mathrm{B}_{12}$. Food folate must be hydrolysed by pancreatic and brush border folate conjugase to monoglutamates prior to absorption in the upper part of the small intestine. It is difficult to summarize our knowledge concerning folate bioavailability in humans, because only a few studies have been carried out and they have given conflicting results (Witthöft and Jägerstad, 2003). In milk, the naturally occurring folate is bound to folate-binding proteins (Öste et al., 1997). According to Girard et al. (2005) folic acid is probably important for the prevention of several diseases such as disease and cardiovascular disease. 
In dairy cows, requirements of folic acid and pantothenic acid cannot be met only by ruminal synthesis (NRC, 2001). Studies have also been presented indicating production and health benefits when dairy cow diets are supplemented with B vitamins (NRC, 2001). As mentioned above, there is an interaction between folic acid, methionine and vitamin $B_{12}$. Girard et al. (2005) have shown that supplementary folic acid increased crude protein and also casein concentrations in milk, however, if the cows were fed rumen-protected methionine the effect of folic acid disappeared. Supplementation of dairy cow diet with folic acid or methionine increased the concentration of folic acid in milk.

Thiamin $\left(B_{\nu}\right)$. The predominant origin of thiamine in milk is biosynthesis in the rumen (Fox and McSweeney, 1998). Thus, thiamine concentration in milk is not considered to be influenced by feed, breed or season to any great extent, but the literature is inconsistent on these points. Shaver and Bal (2000) found that supplementation with thiamine increased milk yield and milk fat and milk protein in two experiments and the opposite in a third experiment. They concluded that dairy cows on diets with a low fibre content and a high content of non-fibre carbohydrates given supplementary thiamine responded by an increase in milk yield. No information was given about the concentration of thiamine in milk.

Vitamin $B_{12}$. Vitamin $\mathrm{B}_{12}$ is a common term for a group of cobalt-containing compounds, which are biologically active in humans (NNR, 2005). Vitamin $B_{12}$ is unique among the vitamins in that it is the largest and most complex and because it contains the metal ion, cobalt (Brody, 1994). Good dietary sources of vitamin $\mathrm{B}_{12}$ for humans are mainly animal-derived products, and vegan diets are thus almost devoid of vitamin $B_{12}$ (Biesalski and Back, 2003). The major effect of $B_{12}$ deficiency is growth impairment, particularly of rapidly growing cells, such as immature red blood cells, and macrocytic hyperchromic anaemia is a common symptom in both vitamin $\mathrm{B}_{12}$ and folate deficiency. Neurological disorders are also characteristic of vitamin $\mathrm{B}_{12}$ deficiency. Vitamin $\mathrm{B}_{12}$ deficiency is manifested years after the onset of nutrient imbalance or functional disorder, because the body pool is large.

Vitamin $B_{12}$ is a cofactor for only two known human enzymes. The major proportion of vitamin $B_{12}$ in foodstuffs is bound to a specific protein (Biesalski and Back, 2003). Absorption of vitamin $B_{12}$ in humans is a multistep process (NNR, 2005). Protein-bound vitamin $B_{12}$ in foods must be cleaved from the protein and absorption requires a glycoprotein, i.e. an intrinsic factor, secreted by the parietal cells of the stomach. The only natural source of vitamin $B_{12}$ is microbes and, hence the predominant source of $\mathrm{B}_{12}$ for cows, and hence in milk, is biosynthesis by rumen microorganisms (Öste et al., 1997; NRC, 2001). The only time vitamin $\mathrm{B}_{12}$ deficiency could be expected in a cow with a well-functioning rumen is when the cow has a cobalt deficiency. Normally, feedstuffs from plants and animals will 
contain enough cobalt. There are examples indicating that forage growing on soils with a low content of cobalt may contribute to vitamin $B_{12}$ deficiency (NRC, 2001). In other words; the content of vitamin $\mathrm{B}_{12}$ in milk depends on the cobalt intake of the cow. According to Schwab et al. (2006), who investigated the apparent synthesis of B-vitamins, the most favourable dairy cow diet for vitamin $\mathrm{B}_{12}$ synthesis was $35 \%$ forage and $30 \%$ non fermented carbohydrates (NFC) in diet. Increasing the sugar content in the diet increased vitamin $\mathrm{B}_{12}$ synthesis. As mentioned, vitamin $\mathrm{B}_{12}$ supplementation of dairy cow diet increased vitamin $\mathrm{B}_{12}$ in milk by over $200 \%$ (Girard and Matte, 2005). Hydroxycobalamin is the predominant form of vitamin $\mathrm{B}_{12}$ in cow's milk. Over $95 \%$ of the vitamin $\mathrm{B}_{12}$ in milk is protein bound.

Vitamin C. Ruminants from approximately the age of three weeks synthesize vitamin C. Vitamin C, or ascorbic acid, as it is also known, can function as an antioxidant (NRC, 2001). Changing the concentration of ascorbic acid in milk could affect the development of oxidized flavour in milk (Barrefors et al., 1995). In a trial involving supplemental dietary vitamin $C$, plasma concentrations of ascorbic acid increased, but this was not reflected by an increased concentration of ascorbic acid in milk (Weiss, 2001).

In summary; the fat-soluble vitamins $\mathrm{A}$ and $\mathrm{E}$ are correlated to the fat content in milk. Both vitamin A and E concentrations in milk can be altered by changes in dairy cow diet. Preferable diets are pasture and/or high-quality forage. The most important factors in rumen synthesis of B vitamins are a well-functioning rumen with both high-quality forage and easily soluble carbohydrates.

\section{DISCUSSION}

Finding a dairy cow diet or natural feeding that ensures the optimal milk quality regarding vitamin and mineral content could be simple or may involve a great deal of research. The simple answer is that the "natural" dairy cow diet is probably best in many ways. A dairy cow diet based on grass or pasture or both, provides a stable environment, which promotes the production of vitamin A and $\mathrm{E}$ and several $\mathrm{B}$ vitamins. Havemose et al. (2004) investigated the influence of type of roughage on the concentration of, for example, riboflavins, tocopherols, carotenes and luteins, and concluded that the concentrations of these components were higher in grass silage than in maize silage. This is probably also the explanation of the difference in the concentration of $E$ vitamins in conventional and organic Danish milk reported by Nielsen (2005). However, one objection against the "natural" diet is that feed is produced on the farm. Home made feed, could have several shortcomings, for example, lack of Se or I, depending on the status of these trace minerals in the soil. 
A great deal of research could be done to determine the most beneficial mineral and vitamin contents in milk. However, the macro-minerals $\mathrm{Ca}, \mathrm{P}$ and $\mathrm{Mg}$ are in homeostasis with the skeleton, which acts as a reservoir of these elements, and it is a difficult to change their content in milk by changing dairy cow diet. A surplus of $\mathrm{P}$ is regarded as an environmental problem, and any efforts to raise the level in dairy cow milk should be undertaken with care. $\mathrm{Na}$ and $\mathrm{Cl}$ concentrations in milk are considered to be independent of dietary intake (Cashman, 2003). There is also evidence that the intake of salt is too high in the Western world and therefore levels of sodium and chloride in milk should not be increased. Normally, there is no dietary deficiency of the macro-minerals $\mathrm{Na}, \mathrm{Cl}$ and $\mathrm{K}$ and hence, there is no great need to increase the content of these minerals in milk.

Regarding trace elements there is a lack of knowledge on the content in the dairy cow diet and in milk and, more importantly, of the bioavailability of these to both the cow and humans. According to Cashman (2003), $\mathrm{Zn}$ in human milk is more bioavailable than that in bovine milk.

However, when altering the content of vitamins and minerals in bovine milk it is necessary to assess the impact on the overall milk composition and implications on milk quality and processing.

Another aspect is how to change the dairy cow diet to achieve a favourable content of minerals and vitamins. At least in the Scandinavian countries this should be done by altering the feed components and not by parenteral methods, as proposed by Knowles et al. (2006). "Long-acting injectable and/or bolus supplements" are not the way forward. Dairy cows eating natural foods should produce healthy dairy products.

\section{CONCLUSIONS}

The concentrations of Se and I could easily be changed in a favourable way by altering dairy cow diet. However, there is a risk of an excess of these two trace minerals, especially Se. Also, vitamin A and E show a strong correlation with daily intake; a higher concentration of roughage and pasture in dairy cow diets promotes these vitamins. Organic dairy production is probably favourable with respect to vitamins. Such a diet also promotes a well-functioning rumen and therefore also the synthesis of B vitamins. However, when altering the content of vitamins and minerals in dairy cow milk it is necessary to assess the impact on the overall milk composition 


\section{REFERENCES}

Aaes O., Sehested J., Larsen T., 2003. The requirements and support of vitamines to dairy cows (in Danish). In: Kvaegets ernaering og fysiologi . Bind 2 - Fodring og fysiologi. DJF Report Animal Husbandry No. 54. Faculty of Agricultural Sciences, Aarhus University (Denmark), pp.153-177

Atkinson S., Alston-Mills B., Lönnerdal B., Neville M.C., 1995. Major minerals and ionic constituents of human and bovine milks. In: R.G. Jensen (Editor). Handbook of Milk Composition. Academic Press, London

Baldi A., 2005. Vitamin E in dairy cows. Livest. Prod. Sci. 98, 117-122

Barrefors P., Granelli K., Appelqvist L.A., Bjoerck L., 1995. Chemical characterisation of raw milk samples with and without oxidative off-flavor. J. Dairy Sci. 78, 2691-2699

Beitz D.C., 2005. Contributions of animal products to healthy diets. In: Proceedings from Cornell Nutrition Conference for Feed Manufacturers. Cornell University, Ithaca, pp. 117-126

Biesalski H.K., Back E.I., 2003. Vitamin $B_{12}$, nutritional significance. In: H. Roginski, J.W. Fuquay, P.F. Fox (Editors). Encyclopaedia of Dairy Science. Academic Press, London, pp. 2721-2726

Boland M., MacGibbon A., Hill J., 2001. Designer milk for the new millennium. Livest. Prod. Sci. 72, 99-109

Bourne N., Wathes C., McGowaan M., Laven R., 2007. A comparison of the effects of parental and oral administration of supplementary vitamin $\mathrm{E}$ on plasma vitamin $\mathrm{E}$ concentrations in dairy cows at different stages of lactation. Livest. Sci. 106, 57-64

Brody T., 1994. Nutritional Biochemistry. Academic Press., London

Cashman K.D., 2003. Minerals in dairy products. In: H. Roginski, J.W. Fuquay, P.F. Fox (Editors). Encyclopedia of Dairy Sciences. Academic Press, Bodmin, Cornwall (UK), pp. 2051-2065

Cashman K.D., 2006. Milk minerals (including trace elements) and bone health. Int. Dairy J. 16, 1389-1398

Chen J.H., Lindmark-Månsson H., Drevelius P., Tidehag G., Hallmans E., Hertervig E., Nilsson A., Åkesson B., 2004. Bioavailability of selenium from bovine milk as assessed in subjects with ileostomy. Eur. J. Clin. Nutr. 58, 350-355

Christensen B.T., Jörgensen V., Larsen T., Damgaard-Poulsen H., Strandberg M.T., Sörensen P., 2006. Selenium use in Danish agriculture (in Danish). DJF Report Soil Management No. 125, Faculty of Agricultural Sciences, Aarhus Universitet (Denmark)

Debski B., Picciano M.F., Milner J.A., 1987. Selenium content and distribution of human, cow and goat milk. J. Nutr. 117, 1091-1097

Ekholm P., Ylinen M., Varo P., 1993. Selenium content in milk during the selenium fertilization in Finland. Norwegian J. Agr. Sci., Suppl. 11, 211-213

Fairweather-Tait S.J., 1997. Bioavailability of selenium. Eur. J. Clin. Nutr. 51, Suppl 1, 20-23

Flynn A., Cashman K., 1997. Nutritional aspects of minerals in bovine and human milks. In: P.F. Fox (Editor). Advanced Dairy Chemistry. Chapter 7. Lactose, Water, Salts and Vitamins. Chapman \& Hall, New York

Fox P., McSweeney P., 1998. Dairy Chemistry and Biochemistry. Kluwer Academic Plenum Publ., New York, London

Girard C.L., Lapierre H., Matte J.J., Lobley G.E., 2005. Effects of dietary supplements of folic acid and rumen-protected methionine on lactational performance and folate metabolism of dairy cows. J. Dairy Sci. 88, 660-670

Girard C.L., Matte J.J., 2005. Folic acid and vitamin B12 requirements of dairy cows: A concept to be revised. Livest. Prod. Sci. 98, 123-133

Givens D.I., Allison R., Cotrill B., Blake J.S., 2004. Enhancing the selenium content of bovine milk through altereration of the form and concentration of selenium in the diet of the dairy cow. J. Sci. Food Agr. 84, 811-817 
Guéguen L., Pointillart A., 2000. The bioavailability of dietary calcium. J. Amer. Coll. Nutr. 19, 119136

Gustafson G., Salomon E., Jonsson S., 2007. Barn balance calculations of Ca, Cu, K, Mg, Mn, N, P, S and $\mathrm{Zn}$ in a conventional and organic dairy farm in Sweden. Agr. Ecosyst. Environ. 119, 160-170

Havemose M.S., Weisbjerg M.R., Bredie W.L.P., Nielsen J.H., 2004. The influence of feeding different types of roughage on the oxidative stability of milk. Int. Dairy Sci. 7, 563-570

Hetzel B.S., 1998. Iodine-deficiency disorders. In: J.S. Garrow, W.P.T. James (Editors). Human Nutrition and Dietetics. Churchill Livingstone, London, pp. 534-555

Hermansen J.-E., Holm-Nielsen J., Bach-Larsson L., Sejrsen K., 2003. The quality and composition of milk (in Danish). In: F. Strudsholm, K. Sejrsen (Editors). Nutrition and Physiology of Cattle. Issue. 2 - Feeding and Physiology. DJF Report Animal Husbandry No. 54. Faculty of Agricultural Sciences, Aarhus University (Denmark), pp. 341-369

Hermansen J.-E., Badsberg J., Kristensen T., Gundersen V., 2005. Major and trace elements in organically or conventionally produced milk. J. Dairy Res. 72, 362-368

Huth P.J., DiRienzo D.B., Miller G.D., 2006. Major scientific advances with dairy foods in nutrition and health. J. Dairy Sci. 89, 1207-221

Jaster E.H., Ward N.E., 1990. Supplemental nicotinic acid or nicotinamide for lactating dairy cows. J. Dairy Sci. 73, 2880-2887

Jensen R.G., 1995. Water-soluble vitamins in bovine milk. In: R.G. Jensen (Editor). Handbook of Milk Composition. Academic Press, pp. 688-692

Juniper D.T., Phipps R.H., Jones A.K., Bertin G., 2006. Selenium supplementation of lactating dairy cows: effect on selenium concentration in blood, milk, urine an feces. J. Dairy Sci. 89, 3544-3551

Kamiya Y., Kamiya M., Tanak M., Shioya S., 2005. Effects of calcium intake and parity on plasma minerals and bone turnover around parturition. Anim. Sci. J. 76, 325-330

Knowles S.O., Grace N.D., Wurms K., Lee J., 1999. Significance of amount and form of dietary selenium on blood, milk, and casein selenium concentrations in grazing cows. J. Dairy Sci. 82, 429-437

Knowles S.O., Grace N.D., Knight T.W., McNabb W.C., Lee J., 2006. Reasons and means for manipulating the micronutrient composition of milk from grazing cattle. Anim. Feed Sci. Tech. $131,154-167$

Kristensen T., 2003. Strategies and challenge for organic milk production based on home grown feed (in Swedish). Konferens Ekologiskt Lantbruk Vägar-Val-Visioner. Proceedings CUL, SLU, pp. 127-131

Krogh-Jensen S., 2005. The support of vitamines in organic dairy production (in Swedish). In: C. Swensson (Editor). Natural Vitamines. Report No. 7052-P, Swedish Dairy Association, Lund (Sweden), pp. 6-7

Kumpulainen J., Salmenpera L., Simes M.A., Koivistoinen P., Perheentupa J., 1985. Selenium status of exclusively breast-fed infants as influenced by maternal organic or inorganic selenium supplementation. Amer. J. Clin. Nutr. 42, 829-835

Larsen E., Schestad J., 2003. Absorption and metabolism of minerals (in Danish). DJF report Animal Husbandry No. 53. Faculty of Agricultural Sciences, Aarhus University (Denmark), pp. 331-370

Levander O.A., 1991. Scientific rationale for the 1989 recommended dietary allowance for selenium. Amer. Diet. Assn. 91, 1572-1576

Levander O.A., Burk R.F., 1996. Selenium. In: E.E. Ziegler, L.J. Filer (Editors). Present Knowledge in Nutrition. ILSI Press. Washington, DC, pp. 320-338

Lindmark-Månsson H., Fonden R., Pettersson H.-E., 2003. Composition of Swedish milk. Int. Dairy J. 13, 409-425 
Lindmark-Månsson H., Svensson U., Paulsson M., Alden G., Frank B., Jonsson G., 2000. Influence of milk components, somatic cells and supplemental zinc on milk processability. Int. Dairy J. 10, 423-433

Majee D.N., Schwab E.C., Berics S.J., Seymour W.M., Shaver R.D., 2003. Lactation performance by dairy cows fed supplemental biotin and a B-vitamin blend. J. Dairy Sci. 86, 2106-2112

McDowell L.R., Williams S.N., Hidiroglou N., Njeru C.A., Hill G.M., Ochoa L., Wilkinson N.S., 1996. Vitamin E supplementation for the ruminant. Anim. Feed Sci. Tech. 60, 273-296

McRae J., O'Reilly L., Morgan P., 2005. Desirable characteristics of animal products from a human health perspective. Livest. Prod. Sci. 94, 95-103

Meglia G.E., Jensen S.K., Lauridsen C., Persson-Waller K., 2006. Alpha-tocopherol concentration and stereoisomer composition in plasma and milk from dairy cows fed natural or synthetic vitamin E around calving. J. Dairy Res. 73, 227-234

Morrisey P.A., Kiely M., 2003. Vitamin E, nutritional significance. In: H. Roginski, J.W. Fuquay, P.F. Fox (Editors). Encyclopaedia of Dairy Science. Academic Press, London, pp. 2670-2677

Mutanen M., Aspila P., Mykkanen H.M., 1986. Bioavailability to rats of selenium in milk of cows fed sodium selenite or selenited barley. Ann. Nutr. Metab. 30, 183-188

Nadeau E., Johansson B., 2003. Important factors which influence on the content of vitamines in silage. Conference "Organic Production, Proceedings Centre of Sustainable Agriculture". Swedish University of Agricultural Sciences (Sweden), pp. 137-141

Nicholson J.W.G., St-Laurent A.-M., McQueen R.E., Charmley E., 1991. The effect of feeding organically bound selenium and $\alpha$-tocopherol to dairy cows on susceptibility of milk to oxidation. Can. J. Anim. Sci. 71, 135-143

Nielsen H.J., 2005. The influence of production methods on the content of pro/antioxidants in milk (in Danish). Workshop - Health and Organic Production Methods. Internal Report No. 59 (in Danish). Danish Centre for Organic Food and Farming (Denmark), pp. 18-20

Nielsen N., Ingvartsen L.K., 2000. Niacin for dairy cows. DJF Report Animal Husbandry No. 20. Faculty of Agricultural Sciences, Aarhus Universitet (Denmark)

NNR, 2005. Nordic Nutrition Recommendations. Report 3. Nordiska Ministerådet, Copenhagen

Nozière P., Graulet B., Lucas A., Martin B., Grolier P., Doreau M., 2006a. Carotenoids for ruminants: From forages to dairy products. Anim. Feed Sci. Tech. 131, 418-450

Nozière P., Grolier P., Durand D., Ferlay A., Pradel P., Martin B., 2006b. Variations in carotenoids, fat-soluble micronutrients, and colour in cows plasma and milk following changes in forage and feeding level. J. Dairy Sci. 89, 2634-2648

NRC, 2001. Nutrient Requirements of Dairy Cattle. $7^{\text {th }}$ revised Edition. National Academy Press, Washington, DC

O’Brian B., Mehra R., Connolly J.F., Harrington D., 1999. Seasonal variation in the composition of Irish manufacturing and retail milks. 4: Minerals and trace elements. Irish J. Agr. Food. Res. 38, 87-99

Ortman K., Pehrson B., 1999. Effect of selenate as a feed supplement to dairy cows in comparison to selenite and selenium yeast. J. Anim. Sci. 77, 3365-3370

Öste R., Jägerstad M., Andersson I., 1997. Vitamins in milk and milk products. In: P.F. Fox (Editor). Advanced Dairy Chemistry, Chapter 3. Chapman \& Hall, New York

Pennington J.A.T., 1990. Iodine concentrations in US milk: variation due to time, season and region. J. Dairy Sci. 73, 3421-3427

Penniston K.L., Tanumihardjo S.A., 2006. The acute and chronic toxic effects of vitamin A. Amer. J. Clin. Nutr. 83, 191-201

Péréz A., Lorenzo M., Cabrera C., Lopez C., 2002. Influence of enrichment with vitamins and minerals on the bioavailability of iron in cow's milk. J. Dairy Res. 69, 473-481 
Pfeffer E., Beede D.K., Valk H., 2005. Nitrogen and phosphorus nutrition of cattle. In: E. Pfeffer, A. Hristov (Editors). Phosphorus Metabolism in Ruminants and Requirements of Cattle. CABI Publishing, pp. 195-237

Rasmussen M.D., Galton M.D., Pettersson L.G., 1991. Effects of premilking teat preparation on spores of anaerobes, bacteria and iodine residues in milk. J. Dairy Sci. 73, 3421-3427

Renner E., Schaafsma G., Scott K.J., 1989. Micronutrients in milk . In: E. Renner (Editor). Micronutrients in Milk and Milk-Based Food Products. Elsevier Applied Science, London, pp. $1-70$

RIKSMATEN, 1997-98. Dietary habits and nutrient intake in Sweden 1997-98. The second national food consumption survey (in Swedish). Information and Nutrition Department, Swedish National Food Administration, Uppsala (Sweden)

Saikat S.Q., Carter J.E., Mehra A., Smith B., Stewrt A., 2004. Goitre and environmental iodine deficiency in the UK-Derbyshire: A review. Environ. Geochem. Health 26, 395-401

Schwab E.C., Schwab C.G., Shaver R.D., Girard C.L., Putnam D.E., Whitehouse N.L., 2006. Dietary forage and nonfiber carbohydrate contents influence B-vitamin intake, duodenal flow, and apparent ruminal synthesis in lactating dairy cows. J. Dairy Sci. 89, 174-187

Shaver R.D., Bal M.A., 2000. Effect of dietary thiamine supplementation on milk production by dairy cows. J. Dairy Sci. 83, 2335-2340

Spörndly R., 2003. Table of feeds for ruminants (in Swedish). Report No 257. Department of Animal Nutrition and Management, Swedish University of Agricultural Sciences, Uppsala (Sweden)

Swanson E.W., Miller J.K., Mueller F.J., Patton C.S., Bacon J.A., Ramsey N., 1990. Iodine in milk and meat of dairy cows fed different amounts of potassium iodide or ethylenediamine dihydroiodide. J. Dairy Sci. 73, 398-405

Swedish Dairy Association, 1973. Composition of Dairy Milk in Sweden (1966-1971) (in Swedish). Stockholm, Svenska Mejeriernas Riksförening

Swensson C., 2002. Ammonia release and nitrogen balances on South Swedish dairy farms 19971999, Acta Univ. Agr. Sueciae, Agraria 333, SLU, Alnarp

Syrjäla-Qvist L., Aspila P., 1993. Selenium fertilization in Finland: effect on milk and beef production. Norwegian J. Agr. Sci., Suppl. 11, 159-167

Toledo P., Andren A., Björck L., 2002. Composition in raw milk from sustainable productions systems. Int. Dairy J. 12, 75-80

UK Ministry of Agriculture, 2000. Food Surveillance Information Sheet, Number 198, 2000 Iodine in Milk. http://archive.food.gov.uk/maff/archive/food/infsheet/2000/ no198/198milk. htm

Vaskonen T., 2003. Dietary minerals and modification of cardiovascular risk factors. J. Nutr. Biochem. 14, 492-506

von Wowern F., 2006. Genetic factors and dietary salt intake as determinants of blood pressure and risk of primary hypertension. Dissertation. Lund University (Sweden)

Wakabayashi H., Yamauchi K., Takase M., 2006. Lactoferrin research, technology and applications. Int. Dairy J. 16, 1241-1251

Weiss P., 2001. Effect of dietary vitamin C on concentrations of ascorbic acid in plasma and milk.

J. Dairy Sci. 84, 2302-2307

Weiss B., 2005. Sorting through the selenium question. Hoard's Dairyman, September 25, 623

Witthöft C.M., Jägerstad M., 2003. Folates, nutritional significance. In: H. Roginski, J.W. Fuquay, P.F. Fox (Editors). Encyclopaedia of Dairy Science. Academic Press, London, pp. 2714-2721 